\title{
Inclusive Education in Nigeria-A Myth or Reality?
}

\author{
Rasheed Adenrele Adetoro \\ Department of Social Studies, Federal College of Education, Abeokuta, Nigeria \\ Email: radetoro2001@yahoo.com
}

Received 21 August 2014; revised 18 September 2014; accepted 6 October 2014

Copyright (C) 2014 by author and Scientific Research Publishing Inc.

This work is licensed under the Creative Commons Attribution International License (CC BY). http://creativecommons.org/licenses/by/4.0/

\section{(c) (i) Open Access}

\begin{abstract}
As democracy entails freedom of association, so should it be for inclusive education in Nigeria. This paper therefore jettisoned the current practice of segregational effort on special education for the challenged and thereby recommended total inclusive education as a better practice for Nigeria classrooms. Practically, it recommended a policy twist in favour of inclusive education as part of the National Policy on Education as well as adequate retraining of teachers in inclusive education pedagogies and provision of abundant resources to support inclusive education learning.
\end{abstract}

\section{Keywords}

\section{Inclusive, Education, Disabilities, Handicapped, Integration}

\section{Introduction}

Inclusive education is the major challenge facing educational systems around the world (Ainscow, 2004). In some developing countries like Nigeria, inclusive education is thought as an approach to serving children with disabilities within general education settings. Consequently the National Policy on Education in Nigeria states that Special Education is created as a formal special educational training given to people (children and adults) with special needs (Federal Government of Nigeria, 2004: p. 47). However, this is contrary to the international practice where inclusive education is seen "as a reform that supports and welcomes diversity amongst all learners” (UNESCO, 2001).

Then if "all human beings are born free and equal in dignity and rights... and they are to act towards one another in a spirit of brotherhood” United Nations Universal Declaration of Human Rights, (United Nations, 1948); there is the need for Nigeria to re-examine and review her national policy on education in favour of inclusive education rather than the so called "special education". It is even doubtful whether the current National 
Policy on Education (2004) gives much support to the realization of philosophies behind the Universal Basic Education (UBE) in Nigeria. According to Adesina (2006), the philosophies behind the introduction of UBE in Nigeria are three-fold thus:

1) The development of the individual into a sound and effective citizen,

2) The full integration of the individual into the community, and

3) The provision of equal access to education opportunity for all citizens of the country of the primary, secondary and tertiary levels both inside and outside the formal school system (p. 35).

The questions which this paper attempted to answer therefore are:

1) How do we ensure "sound" and "effective" citizenship through inclusive education in Nigeria?

2) How do we ensure full integration of the individual into the community through inclusive education in $\mathrm{Ni}$ geria?

3) How do we provide for "equal access" to education opportunities in Nigeria through inclusive education?

\section{Conceptual Clarification on Inclusive Education}

Inclusive education differs from previously held notions of "integration" and "mainstreaming", which tended to be concerned principally with disability and "special education needs" and implied accommodation of all categories of learners in the classroom (Wikipedia, the Free Encyclopedia, 2014). It is about the child's right to participate in school's duty and programmes regardless of his or her disabilities as against special education that is meant for students with disabilities only. According to the National Centre on Educational Restructuring and Inclusion (1995), inclusive education means:

Providing to all students, including those with significant disabilities, equitable opportunities to receive effective educational services, with the needed supplementary aids and support services, in age appropriate classrooms, in order to prepare students for productive lives as full members of society (p. 1).

Consequently, the aim of inclusive education is to eliminate social exclusion arising from attitudes and responses to diversity in race, social class, ethnicity, religion, gender and ability (Vitello and Mithaug, 1988 cited by Ainscow, 2004). In doing so, efforts are made to ensure that diverse learners-those with disabilities, different languages and cultures, different home and family lives, different interests and ways of learning-are exposed to teaching strategies that reach them as individual learners without the stigmatization that comes with separation (NVPIE—Nevada Partnership for Inclusive Education, nd). Hence, inclusive education amounts to equal opportunities for all learners to learn and succeed in the society.

The Education for All agenda of the 1990 Jomtien World Conference was the platform that gave the first attention to inclusive education. According to the conference report, every person-child, youth and adult should be able to benefit from educational opportunities which would meet their basic learning needs (World Conference for Education for All, 1990). Then came the 1994 Education Report which gave the idea of inclusive education a larger impetus. Equally, the marginalization and exclusion of learners from educational system was seriously addressed at the Dakar World Education forum in April 2000 with the following warning that:

The key challenge is to ensure that a broad vision of Education for All as an inclusive concept is reflected in national government and funding agency policies (UNESCO, 2000).

As a matter of fact, inclusive education is to address the educational needs of all learners in a non-threatening and supportive learning environment in order to include learners who were formally disadvantaged and excluded from education because of "barriers to learning". These barriers may be physical, mental, neurological, mental, emotional, psycho-social, beliefs, colour, racial, religious, socio-economic and gender in nature. Consequently therefore, the UN convention on the Rights of Persons with Disabilities (United Nations, 2006) called on all states parties to ensure an inclusive education system at all levels.

In actual practice, Wikipedia - the free encyclopedia (2014) identified two types of inclusive education thus:

- Partial inclusion where students with special needs are educated in regular classes for nearly all the day, or at least for more than half of the day but would receive specialized services outside the regular classroom such as speech therapy, physical therapy or hearing therapy as the case may require.

- Full inclusion which is the total integration of all students, including those that require the most substantial educational and behavioural supports and services in a regular class. 
Regardless of whatever practice is being adopted for inclusive education therefore, it must be noted that the key elements that are involved are that inclusive education is a process of "never-ending search to find better ways of responding to diversity", to use evidence of various kinds to stimulate creativity and problem-solving in identifying and "removing barriers to education for all", which is about "the presence of all children in schools, and participating to succeed together", with equal consideration for "group of learners who may be at risk of marginalization, exclusion or under achievement” (Ainscow, 2004).

\section{The Current Practice in Nigeria}

By the 2004 Nigeria’s National Policy on Education, a programme known as "Special Education” was designed to cater for three categories of individuals thus:

1) The Disabled including people with physical, visual, hearing, mental, emotional, social, speech, learning and multiple impairments.

2) The Disadvantaged involving the children of nomadic pastorals, migrant fisher folks, migrant farmers, hunters etc.

3) The Gifted and Talented involving people (Children and Adults) who have high intelligent quotient and endowed with special traits in arts, creativity, music, leadership, intellectual precocity etc and therefore find themselves insufficiently challenged by the regular schools (Federal Government of Nigeria, 2004: pp. 47-48).

Furthermore by the provision of the policy, education of children with special needs are expected to be free at all levels and all necessary facilities that would ensure easy access to education shall be provided to include:

a) Inclusive education or integration of special classes and units into ordinary/public schools under the Universal Basic Education (UBE) scheme;

b) Regular census and monitoring of people with special needs to ensure adequate educational planning and welfare programme;

c) Special education equipment and materials like Perkins brailler, white/mobility care, brailed textbooks, abacus, talking watch, audiometers, speech trainers, hearing aids, ear moulding machines, educational toys, calipers, crutches, wheel chairs, artificial limbs, audio-visual equipment and internet facilities;

d) Special education training on braille reading and writing, typewriter use, speech signs, daily living skills;

e) Special training and re-training of the personnel on capacity building to keep them abreast of latest teaching techniques on various categories of disabilities, the gifted and talented; and

f) A teacher-pupil ratio of 1:10 in special schools (pp. 49-50). Equally the special schools are to arrange for effective architectural designs of school buildings with regular sensory, medical and psychological screening assessments to identify any incidence of handicap.

However, a cursory look at the policy itself shows some contradiction and gaps. For examples, the creation of "special schools" negates the principle of inclusive education which is to provide equal access opportunities to education regardless of any barrier. Equally, why would it be that only the children with special needs shall have access to free education at all levels when provisions are not made for developing the children with special needs technically and in sport areas. Indeed, as well remarked by the National Open University of Nigeria (2006), the content of curriculum and delivery strategies both within the regular system and with children with special needs are subject of questioning. This is because it could be observed that preparatory skills on pre-vocational and vocational orientation as well as recreational facilities for the handicapped are either not there or insufficiently provided in the so called "special schools". In a situation where regular classes in the cities are overcrowded to the tune of 1:80 teacher-pupil ratio, the vision on ratio 1:10 for inclusive classes may remain a dream.

The special schools are limitedly scattered all over the country and sometimes named after a particular disability to further stigmatize whoever attends such schools. Examples are "Schools for the blind", "Schools for the Deaf and Dumb", "Schools for the handicapped". Even most of these special schools are either owned by individual philanthropists, non-governmental organizations or religious bodies while only few are run by the government (at most one in a senatorial district, making it not more than five in a state). Even though the UNESCO (2008) statistics shows that over $10 \%$ or 650 million people in the world are disabled with over $80 \%$ of them in developing countries, Nigeria being one of the developing nations lack any census of different categories of her citizens with disabilities talkless of making adequate provision for them. Indeed as cited by Garuba (2003), out of the $10 \%$ perceived disabled children in Nigeria, only $0.42 \%$ are enrolled in schools as against $67.05 \%$ of their 
normal school going counterparts. Worse still, the stereotype cultural belief of illiterate parents that the handicapped children are "children from idols" made adoption of inclusive education in Nigeria a myth rather than a reality. Arising from the various observations therefore, the readiness factor and perhaps the desirability of inclusive education in Nigeria as well remarked by Ademokoya (2003) and re-echoed by Eni-Olorunda (2005) have not been established.

\section{Recommendations}

There is the need for a policy reform to show commitment to inclusive education in Nigeria. This would involve the abrogation of the concept of "special schools" in the Nigeria's National Policy on Education to allow for full social integration of the handicapped into the regular schools and society. Equally, an urgent census specifically to detect the disability of every Nigerian is necessary to ensure adequate planning for inclusive education in $\mathrm{Ni}$ geria. The literacy programmes of the federal government should be vigorously pursued to ensure the removal of the prejudice and stereotype behaviours of people towards the disabled persons. Provisions in the UBE act for disabled children should include adequate learning and recreational facilities and equipment for the handicapped children.

In order to ensure that no child is left behind in curriculum delivery, there is the need for massive retraining of the teachers of regular schools in inclusive education pedagogies and skills. They are also to be trained in evaluative services for disability (Agunloye, Pollingue, Davou, \& Osagie, 2011). As well remarked by Ajuwon (2008), there is the need to conduct comprehensive and methodologically—sound researches into specific needs and interests of each categories of the children with special needs to determine how best to integrate them into the regular class and society. This should equally help in designing cost-effective-universal school buildings that would accommodate everybody (whether disabled or not) with abundant resources to provide education for all in the same setting.

There is the need to create a culturally responsive school environment for the children of the fishermen, the cattle rearers and hunters such that their curriculum is adapted to their traditional job-orientation and modern skills provided for them in the own classroom settings. There is also the need to strengthen the workings of the National Commission for Nomadic Education and that of the Universal Basic Education Commission for effective inclusive education programme. To this end, an increase in budgetary allocation from the current less than $10 \%$ to the UNESCO standard of $26 \%$ of the total Gross Domestic Product is hereby recommended for education. This increase should be devoted to the provision of adequate learning facilities and infrastructures as well as medical personnel (including nurses and physiotherapist) to support inclusive education in Nigeria. After provision of adequate facilities and infrastructures for inclusive education however, there is the need to put appropriate legal framework to sanction anti-inclusive education behaviour in place. This should include an option of fine or a maximum of 1 year imprisonment for any behaviour that is obstructive to the provision of inclusive education in Nigeria.

\section{Conclusion}

There is no doubt that inclusive education is the only means of achieving Nigeria's dream of "a free and democratic society" and “a just and egalitarian society” (Federal Government of Nigeria, 2004: p. 6). It is also a way of combating discrimination and achieving education for all. Even though expensive, inclusive education is the only type of education that can serve "our unity in diversity". Consequently, Nigeria cannot run away from this responsibility and therefore it should be her target for vision 2020.

\section{References}

Ademokoya, J. A. (2003). Advocacy for Inclusion: A Misplacement of Priority. The Staff Seminar. Ibadan: University of Ibadan.

Adesina, S. A. (2006). From Universal Primary Education (UPE) to Universal Basic Education (UBE): The Challenges of Education Innovation in Nigeria. In S. A. Adesina (Ed.), Universal Basic Education in Nigeria: Prospects and Challenges (pp. 31-46). Imeko: African University Institute.

Agunloye, O. O., Pollingue, A. B., Davou, P., \& Osagie, R. (2011). Policy and Practice of Special Education: Lessons and Implications for Education Administration from Two Countries. International Journal of Humanities and Social Science, 1, 90-95. 
Ainscow, M. (2004). Developing Inclusive Education Systems: What Are the Levers for Change? Manchester: The University of Manchester.

Ajuwon, M. P. (2008). Inclusive Education for Students with Disabilities in Nigeria: Benefits, Challenges and Policy Implications. International Journal of Special Education, 23, 12-17.

Eni-Olorunda, J. T. (2005). Inclusive Education in Nigeria: A Myth or Reality? International Journal of Emotional Psychology and Sport Ethics, 7, 72-78.

Federal Government of Nigeria (2004). National Policy on Education. Lagos: NERDC Press.

Garuba, A. (2003). Inclusive Education in the $21^{\text {st }}$ Century: Challenges and Opportunities for Nigeria. Asia-Pacific Disability Rehabilitation Journal, 14, 191-200.

National Centre on Educational Restructuring and Inclusion (1995). National Study of Inclusive Education. New York: The City University of New York.

National Open University of Nigeria (2006). ECE 207: Meeting Special Educational Needs in Early Childhood. Lagos: NOUN, 119-120.

NVPIE—Nevada Partnership for Inclusive Education (nd). The Promise of Inclusive Education. http://nvpie.org/inclusive.html

UNESCO (2000). The Dakar Framework for Action. http://unesdoc.unesco.org/images/0012/001211/121147E.pdf

UNESCO (2001). Open File on Inclusive Education. Paris: UNESCO.

UNESCO (2008). International Conference on Education 48th Session “Inclusive Education: The Way of the Future”. http://unesdoc.unesco.org/images/0018/001829/182999e.pdf

United Nations (1949). United Nations Universal Declaration of Human Rights. http://www.supremecourt.ge/files/upload-file/pdf/act3.pdf

United Nations (2006). Convention on the Right of Persons with Disabilities. http://www.un.org/disabilities/convention/about.shtml

Wikipedia, the Free Encyclopedia (2014). Inclusion (Education). http://en.wikipedia.org/wiki/Inclusion_(education)

World Conference on Education for All (WCEFA) (1990). Meeting Basic Learning Needs: A Vision for the 1990s. http://unesdoc.org/images/0009/000975/097552e.pdf 
Scientific Research Publishing (SCIRP) is one of the largest Open Access journal publishers. It is currently publishing more than 200 open access, online, peer-reviewed journals covering a wide range of academic disciplines. SCIRP serves the worldwide academic communities and contributes to the progress and application of science with its publication.

Other selected journals from SCIRP are listed as below. Submit your manuscript to us via either submit@scirp.org or Online Submission Portal.
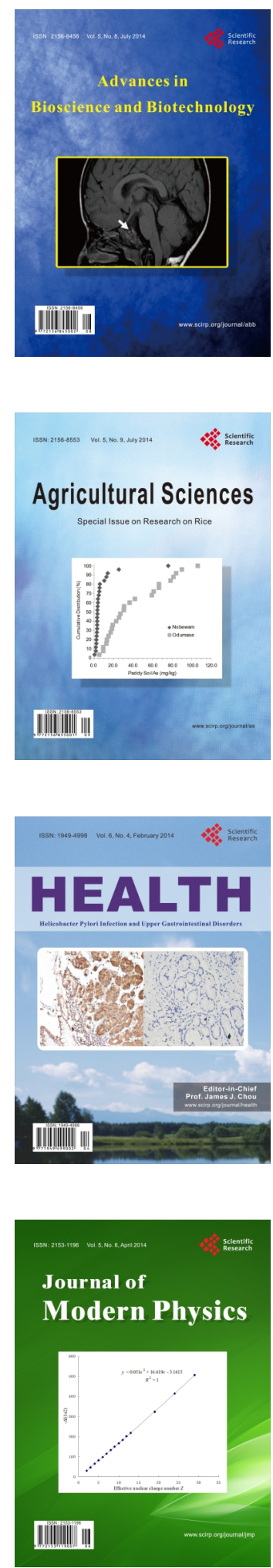
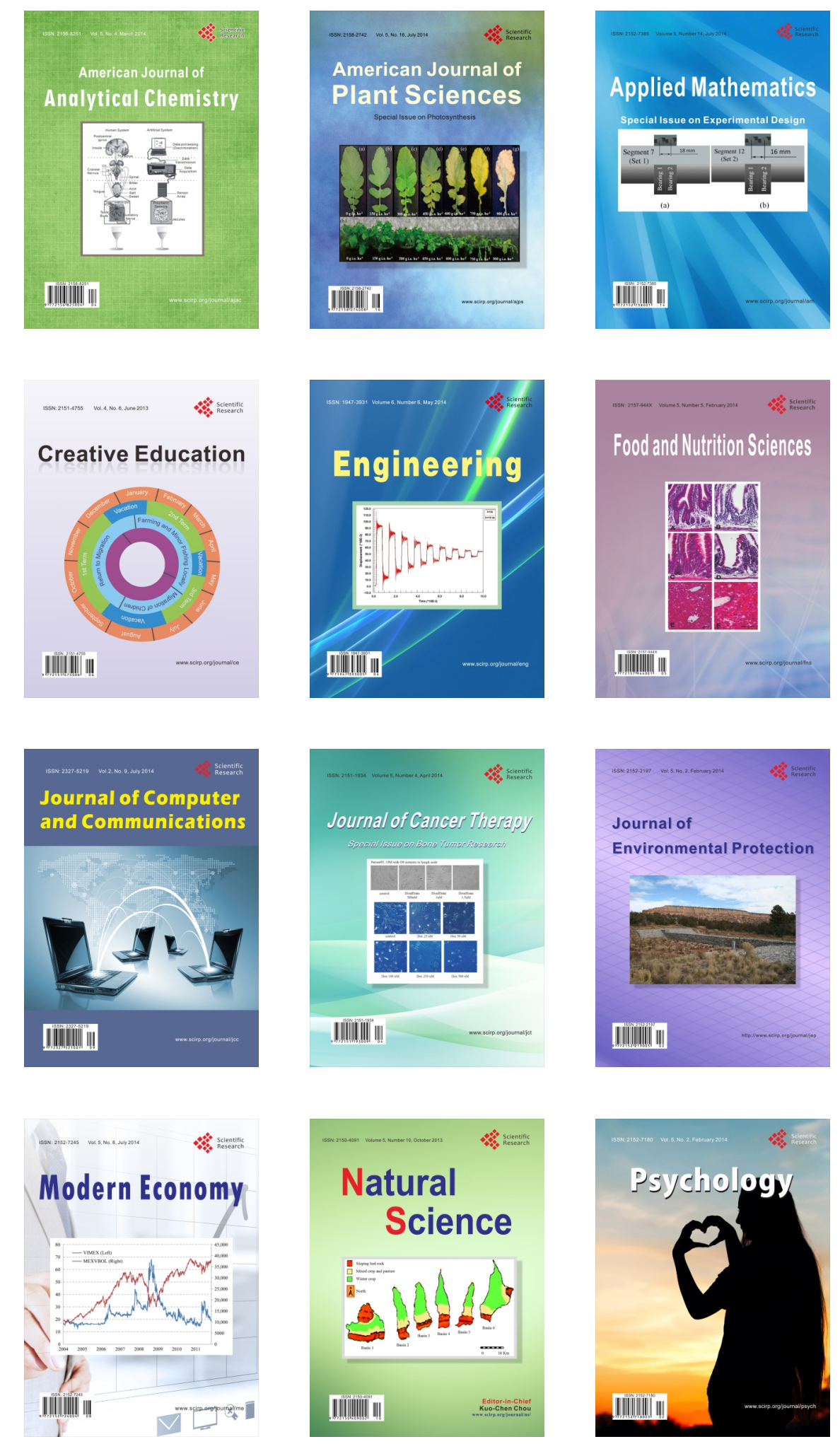